\title{
低放射率表面を持つ内装が室内温熱環境に及ぼす効果に関する研究（その1）： 実大実験室を用いた放射暖房時の室内温熱環境の実測
}

EFFECTS OF LOW EMISSIVITY INTERIOR SURFACES ON THERMAL ENVIRONMENT (PART 1): MEASUREMENTS ON INTERNAL THERMAL ENVIRONMENT WITH RADIANT HEATING USING REAL-SIZE EXPERIMENTAL ROOMS

\author{
石並真 吏*1, 淺田秀男*2, 山田保誠*3 \\ Maori ISHINAMI, Hideo ASADA and Yasusei YAMADA
}

\begin{abstract}
We studied effects of the low-emissivity (low-E) interior surface material on interior thermal environment using radiant heating by comparing two real-size experimental rooms with the same thermal insulation: one is covered with a low-E material, (Low-E room), and the other is covered with a normal interior material (Std-E room). As a result, the globe and air temperatures of the Low-E room increased rapidly and showed about $0.8^{\circ} \mathrm{C}$ higher temperatures than those of Std-room. The increase in temperatures of the Low-E room may be because the whole Low-E surface, except for floor, of the room become pseudo radiant heating surface.
\end{abstract}

Keywords : Low emissivity, Interior surface, Radiant heating, Thermal environment, Real-size experimental room 低放射, 内装表面, 放射暖房, 温熱環境, 実大実験室

\section{1. はじめに}

現在、居住空間の温熱環境を調整する手法として、主に対流式冷 暖房が用いられている。この方式は室内の空気を直接冷却もしくは 加温し、強制的に空気を対流させることにより短時間で室温を制御 することが可能である。しかし、壁や床などの表面温度を直接制御 できないため、体感温度は暖房時低く、冷房時高く感じることがあ る。また、冷暖房装置の吹き出し口からの冷風や温風が直接肌にあ たると、過剩な寒さや暑さによる不快感を生じる恐れがある。一方 放射冷暖房は、吹き出し口からの風はなく、直接及び間接的に放射 により人体と熱をやりとりするため比較的快適性が高いという長所 がある例えば 1,2),3)。そのため、建築空間の熱的快適性を一層向上させ るためには、室内の温度・湿度のみならず熱放射環境も積極的に調 整することが重要と考える。一般的な建築内装材の遠赤外域での放 射率は 0.9 程度である。そのため、放射暖房機器等から発せられる 約 $90 \%$ の遠赤外線は室内空間の表面において一度吸収され、表面の 絶対温度に応じた遠赤外線が再放射されるプロセス(吸収一再放射 プロセス)を繰り返す。したがって、機器等からの遠赤外線が最終的 に人体表面に届くまでには時間遅れ等が生じる。より効果的な放射 暖房を行うには、室内の表面温度を適切に維持するため建物外皮の
高断熱化が重要である。国土交通省の統計データ、事業者アンケー 卜等による推計 ${ }^{4}$ から、既存住宅約 5000 万戸のストックにおいて、 平成 11 年基準を満たす住宅は約 $5 \%$ 程度にとどまっており、断熱性 能が不十分である住宅が大半を占めている。今後、リフォーム適齢 期の既存住宅数は急速な増加が予想されるが、従来の断熱リフォー ムは大掛かりな工事であるため実施は進んでいない5)。既存建物の 満足度を調查した文献 6)によると、より古い住宅ほど高価格なリフ オームを実施し、かつリフォーム寸る箇所が増加する傾向にある。 そこで室内表面の放射率を低くすることができれば、放射暖房機器 からの遠赤外線の反射を大きくすることが可能となる。これにより 放射暖房において、室内表面における吸収一再放射プロセスを経ず に人体表面に放射による熱が届くと期待される。さらに、低放射率 表面を持つ内装材(以下、低放射率内装材と記寸)を用いれば、既存建 物でも比較的簡易的な壁面改修のみで、放射暖房の立ち上がりの遅 さを改善し、室内の熱放射環境を向上させつつ、機器の設定温度を 下げることが可能となり、暖房用エネルギー使用量の削減が予想さ れる。

本研究では、低放射率内装材を建築室内空間に用いた際に形成さ れる室内温熱環境や、放射冷暖房と組み合わせたときの効果を定性

\footnotetext{
·1国研）産業技術総合研究所リサーチアシスタント・修士（学術） 愛知淑徳大学大学院文化創造研究科文化創造専攻＼cjkstart修士（学術） 愛知淑德大学創造表現学部創造表現学科教授・博士 (工学) (国研) 産業技術総合研究所 研究グループ長・博士 (工学)
}

Research Assist., AIST, M.A. / Grad. Student, Dept. of Creativity and Culture, Graduate School of Creativity and Culture, Aichi Shukutoku Univ., M.A. Prof., Fac. of Creation and Representation, Aichi Shukutoku Univ., Dr.Eng. Group Leader, AIST, Dr.Eng. 


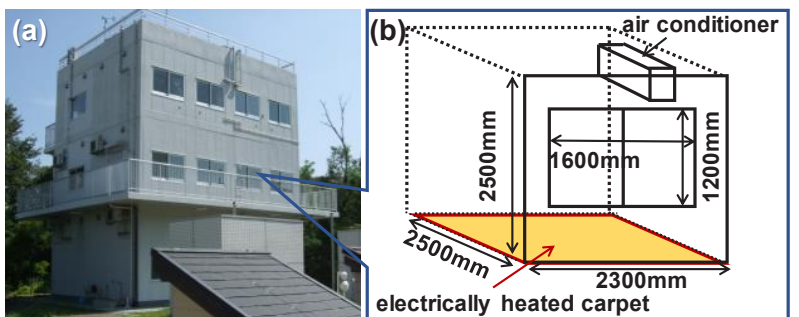

(c)

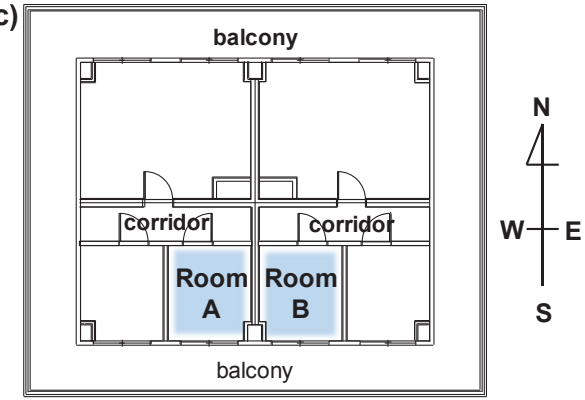

Fig. 1 The exterior of experimental building (a), the dimension of the experimental room (b), and the plan of the $2^{\text {nd }}$ floor of the building (c).

的に明らかにするため、実大実験室での実測を行った。本報その 1 では、実大実験室の内壁面に低放射率内装材としてアルミ馢を貼付 した「低放射率室」と通常の高放射率内装材である「標準室」の 2 部屋においてホットカーペットで放射暖房した際の、室内温熱環境 を比較し、低放射率内装材が室内温熱環境に及ぼす効果について検 証した。

\section{2. 実験方法}

\section{1 実大実験室の概要}

実証実験は産総研中部センター内の 3 階建ての環境調和型建材実 験棟(Fig. 1 a)で行った。実験棟は鉄骨造で、単板、アルミサッシ、 断熱材の厚みが $25 \mathrm{~mm}$ であり、断熱性能は昭和 55 年の省エネ基準 程度となっている。当該実験棟 2 階と 3 階には南に面した同寸法(幅 $2300 \mathrm{~mm} \times$ 奥行 $2500 \mathrm{~mm} \times$ 高さ $2500 \mathrm{~mm}$ ) の実験室が 4 つ並んでおり、 南面に幅 $1600 \mathrm{~mm} \times$ 高さ $1200 \mathrm{~mm}$ の空がそれぞれ 1 つ設置されて いる(Fig. 1 b)。温熱環境測定の比較には、2 室が同一の断熱性能で あることが望ましい。そこで、外気に面している壁が南側 1 面だけ であり、両端が部屋に挟まれており、また 1 階と 3 階の部屋にも挟 まれている 2 階の中央の 2 室(A 室、B 室)を用いた(Fig. 1 c)。また、 放射暖房による温熱環境の変化を実測するに際し、日射の影響を排 除するため、両室の空ガラスの外気側全面にアルミ箔を貼付した。 室内には、ヒートポンプ式エアコン(ダイキン工業製 S36JTNV-W) と幅 $1950 \mathrm{~mm} \times$ 長さ $2350 \mathrm{~mm}$ で、床面積の約 $80 \%$ を占めるホット カーペット(アイリスオーヤマ製 HCM-T2420)が設置されている。

\section{2 温熱環境測定}

室内の表面温度の測定点及び位置は、天井面(1 面)、壁面(4 面)が それぞれの面の中央付近で 1 点ずつ、床面は塩化ビニル床材表面で 1 点と、床ホットカーペット上で 1 点を計測した。表面温度の測定 には、 $\mathrm{T}$ 型熱電対(直径 $0.32 \mathrm{~mm}$ 、ビニル被覆、クラス 1 )を用いた。 熱電対の測温接点は文献 7)準じて作成し、同 8)に示されている接

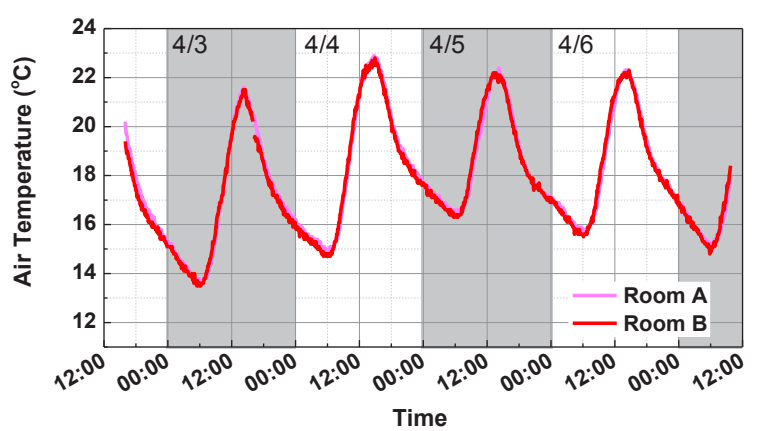

Fig. 2 Variations of air temperature in the center of each room (A and $B$ ) with standard emissivity interior surfaces during the period from $2^{\text {nd }}$ to $7^{\text {th }}$ of April in 2020.

触による表面温度測定方法に準じてアルミテープで表面に貼り付け た。また、テストー製マルチ環境測定器 testo400を実験室中央部に 設置して、グローブ温度・空気温度・気流速を測定した。さらに、 Optris 社製サーモグラフィーPI640を用いて、A 室では西南向き、 B 室では東南向きに設置し、室内の放射温度画像を撮影した。熱画 像撮影時の測定対象面の放射率設定值は、A 室・B 室ともに 1.0 と した。低放射率室である B 室においても放射率設定值を 1.0 とした のは、室内表面から放たれる(低放射率室においては、表面に入射し 反射する)長波長放射エネルギーが、一般的な放射率の室内表面から 放たれると仮定したときの仮想の表面温度を把握し比較するためで ある。なお、本報では熱電対を用いて計測した表面温度と上記の仮 想の表面温度とを明確に区別するため前者を「熱電対表面温度」、後 者を「放射温度」と記す。

\section{3. 実験結果}

\section{1 測定対象の 2 室の断熱性能差の確認}

A 室と B 室の断熱性能がほぼ同様と見なせるか確認するために、 B 室の内壁表面に低放射率内装材としてアルミ箔を貼付する前に、 室内表面内装が同じ状態で自然室温を測定し、2 室の断熱性能を評 価した。

Fig. 2 に、 4 月 2 日から 7 日の 6 日間の同一の内装材(高放射率内 装材)の状態における 2 室の室内中心空気温度を測定した結果を示 す。測定には熱電対を用い、5 分間隔で測定した。Fig. 2 に示した 期間中、 2 室はほぼ同じ温度変化であり、6 日間の気温差の平均は $0.1^{\circ} \mathrm{C}$ 以下であった。以上から測定対象の 2 室はほぼ同一の断熱性能 であることを確認した。
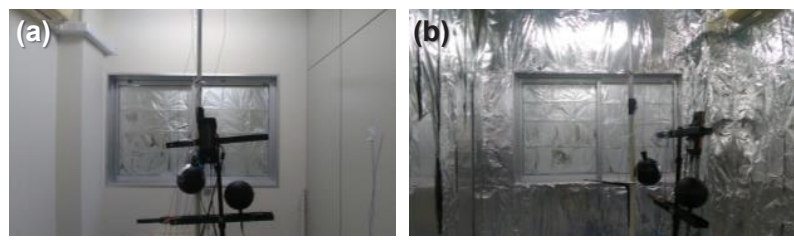

Fig. 3 Interiors of the Room A with standard emissivity wall surface (a) and the Room B with low emissivity wall surface, aluminum foil, (b). 


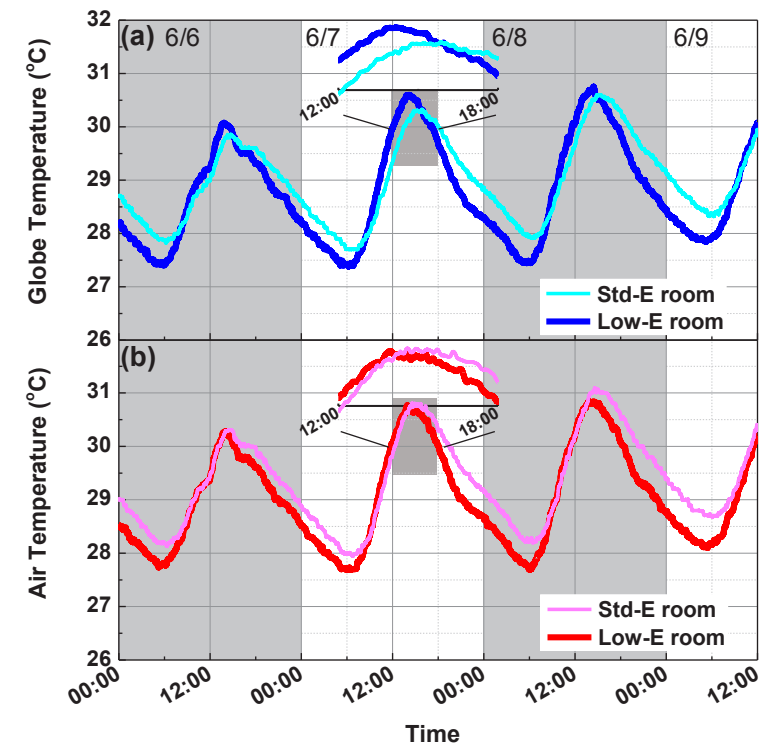

Fig. 4 Variations of globe (a) and air (b) temperatures for the standard emissivity (Std-E) room and the low emissivity (Low-E) room during the period from $6^{\text {th }}$ to $9^{\text {th }}$ of June in 2020. The enlarged figures of the variations from 12:00 to 18:00 on $7^{\text {th }}$ of June are also shown.

\section{2 内装材の低放射化による温熱環境の変化}

室内表面の低放射化が室内温熱環境に及ぼす影響を明らかにする ために、2 室による比較実験を行った。通常の高放射率の壁表面材 である「標準室」(Fig. 3a：A 室) と、部屋の床を除く室内壁表面全 てに低放射率内装材として放射率約 0.1 のアルミ簿を貼付した「低 放射率室」(Fig. 3b：B 室)を用意し、冷暖房を行わなかった際、屋 外気温の変化が標準室と低放射率室の室内温熱環境に及ぼす影響を 調べた。低放射率室のアルミ箔は、接着剤を用いずに水で濡らして 貼付した。

Fig. 4 に、 6 月 6 日から 9 日の 4 日間におけるグローブ温度(a)、 空気温度(b)の測定結果を示す。測定は 5 秒間隔で行った。Fig. 2 と 比較すると標準室と低放射率室では、明瞭な温度差が確認できる。 グローブ温度、室内空気温度ともに標準室では 15:00 あたりから下 降するのに対して、低放射率室では 14:00 あたりから標準室より速 やかに下降した。さらに、低放射率室では、6:00 あたりからより両 温度が速く上昇した。また、最高気温、最低気温に達する時刻は、 空気温度では標準室と低放射率室とでほとんど差はなかったが、グ ローブ温度では低放射率室が標準室より明らかに速く、顕著な差が 観察された。また 6 月 6 日から 8 日の 3 日間における標準室と低放 射率室のグローブ温度の日最高温度の平均は、 $30.2^{\circ} \mathrm{C}$ と $30.5^{\circ} \mathrm{C}$ で低 放射率室が $0.3^{\circ} \mathrm{C}$ 程度高く、日最低温度の平均は、 $28.1^{\circ} \mathrm{C}$ と $27.4^{\circ} \mathrm{C}$ で低放射率室が $0.7^{\circ} \mathrm{C}$ 程度低かった。一方、標準室と低放射率室の 日最高空気温度の平均は、それぞれ $30.7^{\circ} \mathrm{C}$ と $30.6^{\circ} \mathrm{C}$ でほぼ同じであ ったが、日最低空気温度の平均は $28.1^{\circ} \mathrm{C}$ と $27.7^{\circ} \mathrm{C}$ で低放射率室が $0.4^{\circ} \mathrm{C}$ 程度低かった。一日の温度変化を比較すると、グローブ温度の 最高温度と最低温度の差は標準室では $2.4^{\circ} \mathrm{C}$ 対して、低放射率室 では $3.1^{\circ} \mathrm{C}$ と、 $0.7^{\circ} \mathrm{C}$ ぼの差があり、一日の温度変化の幅が大きか

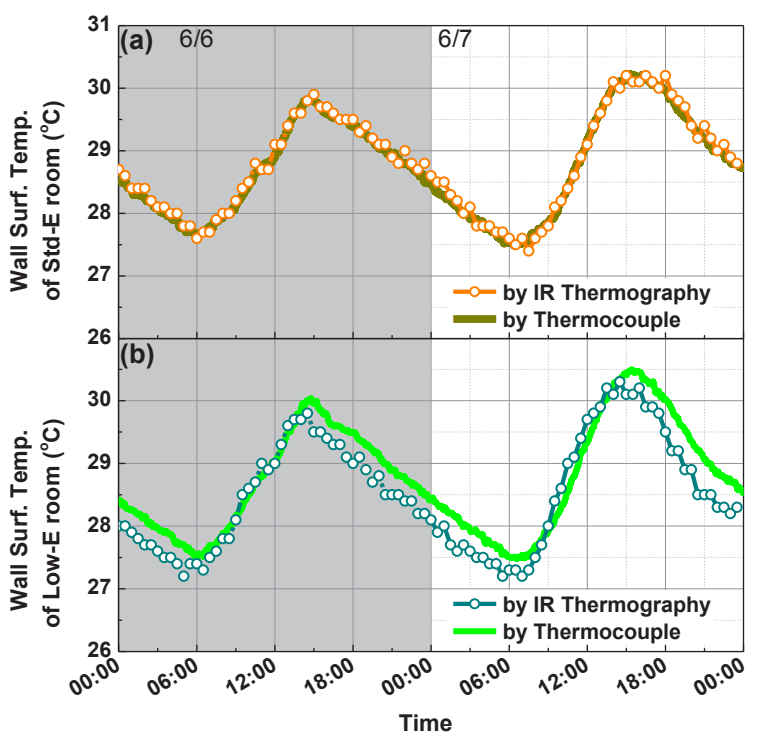

Fig. 5 Variations of wall surface temperatures measured by the IR thermographies and thermocouples for the Std-E room (a) and the Low-E room (b) during the period from $6^{\text {th }}$ to $7^{\text {th }}$ of June in 2020.

った。以上より、日最高温度、日最低温度に達する時刻、温度変化 幅ともに空気温度よりグローブ温度が低放射化による影響を受けた ことが確認できる。しかし、それらの温度差は $1{ }^{\circ} \mathrm{C}$ 以内であるため、 両室の挙動には大きな差はないと判断できる。

次に、サーモグラフィーを用いて室内表面の熱画像を 30 分間隔 で撮影した。室内表面の各部位の放射温度は、サーモグラフィーの 熱画像生データを専用の解析ソフトを用いて算出した。このとき表 面放射率の設定值を 1.0 として算出した表面温度は、標準室におい ては熱電対表面温度と放射温度との比較に、低放射率室においては 室内放射環境の違いを表面放射率が 1.0 の一般的な建築空間に置き 換えた空間で比較するために用いる。Fig. 5 に、6 月 6 日から 7 日 の 2 日間における標準室(a) と低放射率室(b)の放射温度と熱電対で 測定した壁表面温度を示す。壁表面温度は標準室では西面、低放射 率室では東面を測定した。標準室では、放射温度と熱電対による温 度との平均温度差は $0.1^{\circ} \mathrm{C}$ であり、誤差と見なせるほど小さい。低 放射率室の熱電対表面温度と放射温度との温度差は、両日の 6:00〜 15:00の時間帯では $0.2^{\circ} \mathrm{C}$ 程度と非常に小さかった。それ以外の時間 帯では放射温度の方が熱電対表面温度より $0.4^{\circ} \mathrm{C}$ 程度低い傾向があ った。熱電対で測定した両室の壁表面温度の平均温度差はほぼなく $\left(0.02^{\circ} \mathrm{C}\right)$ 、最高・最低温度を示寸時刻も同じであった。そのため、低 放射率室の放射温度だけが異なる温度を示すことが判明した。

\section{3 放射暖房時の室内温熱環境}

冷暖房を行わなかった場合、標準室と低放射率室の温熱環境に大 きな差がないことを確認したので、ホットカーペットを用いて床放 射暖房を行った際の 2 室の室内温熱環境を 6 月中旬から 7 月中旬に かけて実測した。放射暖房は比較的外気温が低い 0:00〜 6:00で行っ た。実測日は一般的な暖房期とは異なるが、使用したホットカーペ ットは表面温度を制御するだけで室温に連動する機能がないため、 


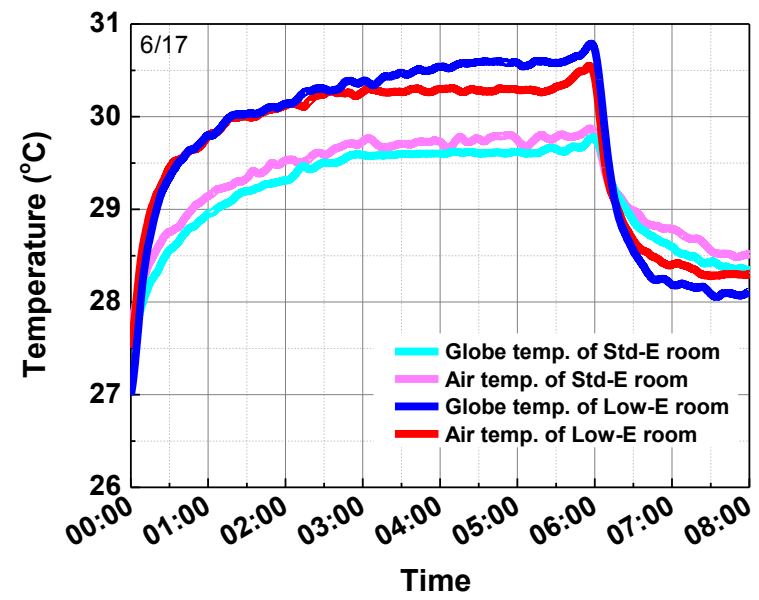

Fig. 6 Variations of globe and air temperatures for the Std-E room and the Low-E room with the floor radiant heating during the period from 0:00 to 8:00 on $17^{\text {th }}$ of June in 2020 .

放射暖房の効果を検証することが可能と考えた。測定項目としては、 熱電対を用いた室内空気温度、グローブ温度、室内表面温度(天井面、 4 面の壁面)を 5 秒間隔で測定し、サーモグラフィーを用いて室内表 面の放射温度画像を 23:59〜0:10の間は 10 秒間隔、0:30〜24:00 は 30 分間隔で撮影した。なお、ホットカーペットの 5 段階ある熱さを 調整するスイッチは、両室とも真ん中を選択した。

Fig. 6 に、6 月 17 日 0:00〜8:00 の標準室と低放射率室における、 それぞれのグローブ温度と室内空気温度の測定結果を示す。ホット カーペットの電源投入直後から、低放射率室のグローブ温度・室内 空気温度はともに標準室のそれらよりも急速に上昇し、電源を切る $6: 00$ の時点では $1^{\circ} \mathrm{C}$ 程度高温になり、その後、低放射率室のグロー ブ温度・室内空気温度はともに急激に下降し、30 分後には標準室よ りも低い温度であった。ホットカーペットの 6 時間の消費電力量は 両室とも $2.64 \mathrm{~kW}$ と同じであったため、室内壁表面の低放射化によ って床放射暖房の立ち上がり時間の短縮、暖房効率の向上や、暖房 負荷の低減が期待される。Fig. 4 からも明らかなように、標準室と 低放射率室の断熱性能がほぼ等しいことから、これらの要因は部屋 の断熱性能の向上によるものではないことがわかる。電源投入直後、

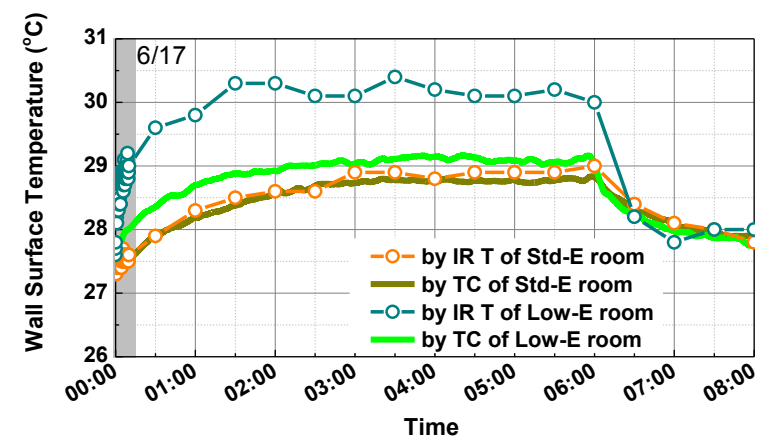

Fig. 7 Variations of wall surface temperatures measured by the IR thermographies and thermocouples for the Std-E room and the Low-E room during the same period as Fig. 6.

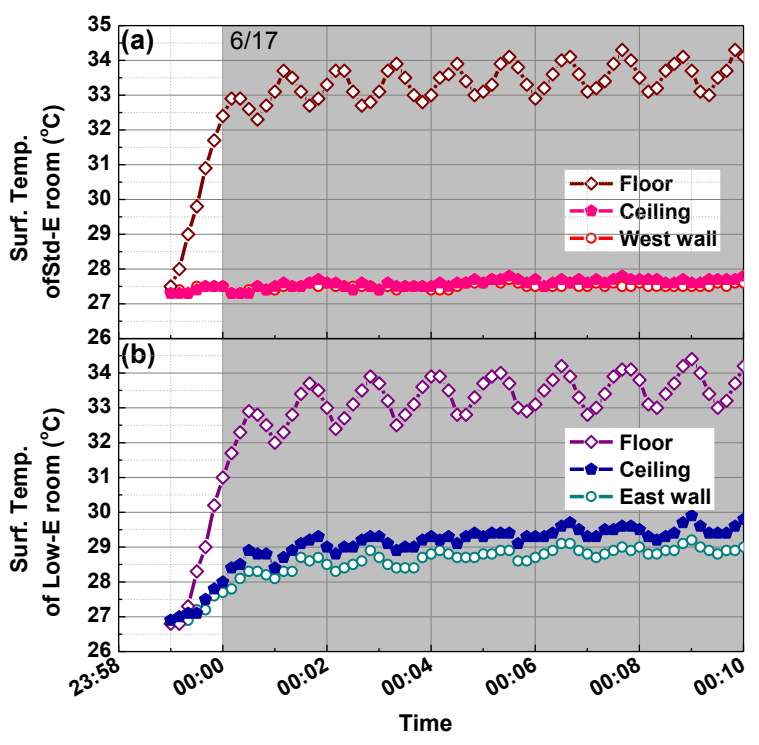

Fig. 8 Variations of surface temperatures of the floor, ceiling and wall measured by the IR thermographies for the Std-E room (a) and the Low-E room (b) during the period from 23:59 on $16^{\text {th }}$ to $0: 10$ on $17^{\text {th }}$ of June, hatched period of Fig. 7

低放射率室の室内空気温度が最も速く上昇したが、 30 分から 1 時間 後には、低放射率室のグローブ温度が空気温度より高くなった。ま た、標準室では常に空気温度がグローブ温度よりも高かった。6:00 時点の温度を高い順に並べると、低放射率室のグローブ温度、低放 射率室の室内空気温度、標準室の室内空気温度、標準室のグローブ 温度となった。これは床放射暖房を行った模型実験と同様の結果で あった 9)-12)。

Fig. 7 に Fig. 6 と同時刻の標準室(西壁)と低放射率室(東壁)の放 射温度と熱電対で測定した壁表面温度を示す。標準室では、放射温 度と熱電対の温度差は平均で $0.1^{\circ} \mathrm{C} 、$ 最大でも $0.3^{\circ} \mathrm{C}$ あ゙り、Fig. $5(\mathrm{a})$ と同様、放射温度と熱電対の温度がほぼ同じであった。これに対し て低放射率室では、ホットカーペットに通電している際に放射温度 が熱電対の温度より平均で $0.9^{\circ} \mathrm{C}$ 、最大で $1.4^{\circ} \mathrm{C}$ 高温となった。電源 を切るとその差は急激に減少し、標準室の放射温度や熱電対での壁 表面温度との差もわずかとなった。この放射温度と熱電対の温度の 挙動は、Fig. 5(b)で示した放射暖房を行わない際とは大きく異なる。 さらに、放射温度の変化が熱電対の温度のそれより急峻であった。 以上より、放射温度と熱電対の温度の差は、内装を低放射化するこ とによって放射暖房時の熱放射環境の変化が標準室のそれより大き いことに起因すると示唆される。

\section{4. 標準室と低放射率室との温熱環境の差異に関する考察}

低放射化による放射暖房時の熱放射環境の変化を考察するため、 放射暖房開始直前の 6 月 16 日 23:59 から 17 日 0:10 まで(Fig. 7 で 網掛した時間帯)の床表面、壁表面、天井表面の放射温度の詳細な变 化を調べた。Fig. 8 に結果を示す。放射暖房面である床表面の放射 温度は、両室ともホットカーペットの温度調整機能に起因すると考 えられる周期的な振動が観察され、同様の温度上昇を示した。壁表 


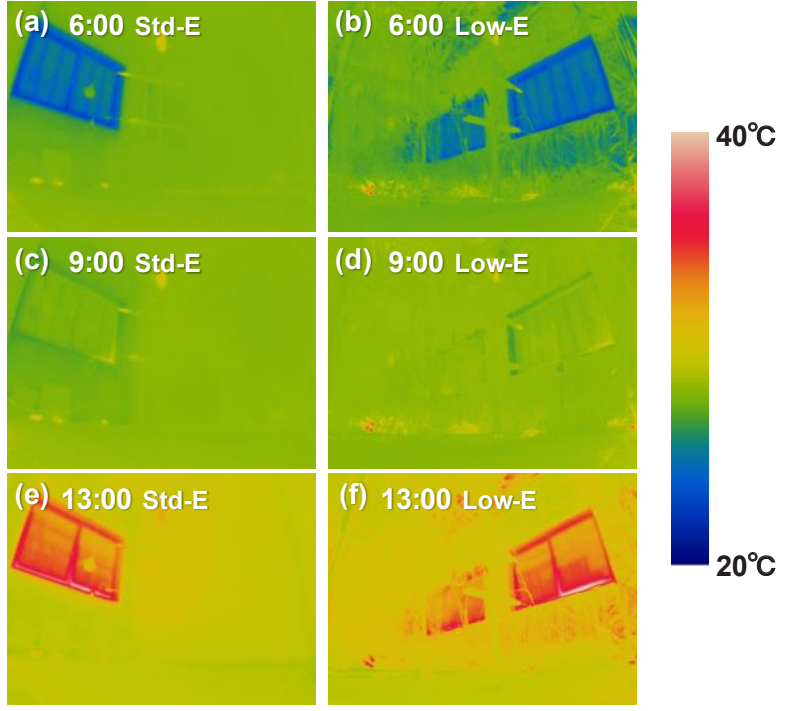

Fig. 9 Radiant temperature distribution images of the Std-E room, left hand side and the Low-E room, right hand side at 6:00(a)(b), 9:00(c)(d) and 13:00(e)(f) on $7^{\text {th }}$ of June in 2020 .

面と天井表面の放射温度は、標準室ではホットカーペットの電源を 投入しても上昇の速さが非常に遅く、ほとんど変化が見られなかっ た。これに対して低放射率室では、電源投入直後に約 $2^{\circ} \mathrm{C}$ 上がり、 その後も徐々に上昇する傾向にあった。

さらに、床表面で観察される温度の振動と同じ周期でかつ山と谷 の位置も等しい温度の振動が観察された。これは、ホットカーペッ 卜から放出される遠赤外線が壁や天井に吸収されないで反射によっ て室内に拡散し、この遠赤外線を放射温度画像として捉えているた めと考える。電源投入直後に壁・天井の放射温度が上がることから、 内装を低放射化することで、疑似的に、全面が放射暖房面であるよ うな空間となったと推測され、これによって Fig. 6 に示すように低 放射率室が標準室より速く空気温度・グローブ温度ともに上昇した と考える。また、壁表面よりも天井表面が高い温度を示した。これ は暖房面と天井面が対面しているため、側面の壁よりも形態係数が 大きいためである。

Fig. 5 で示したように、サーモグラフィーで測定した低放射率室 の放射温度だけ、他の壁表面温度と異なる挙動を示した。Fig. 8 よ り、低放射率室の放射温度は非常に高い応答性を有しており、この 応答性の高さがこの挙動に起因していると示唆される。そこで、各々 の部屋の放射温度の分布を解析した。Fig. 9 に終日放射暖房を行わ なかった 6 月 7 日の 6:00、9:00 および 13:00 における標準室と低 放射率室の放射温度画像を示寸。6:00 における標準室(Fig. 9 a)では 温度が低いことを示寸青い箇所が空部だけに限られる。一方、低放 射率室では、本来 1 個しかないはずの空部が 2 個あるように観察さ れる(Fig. 9 b)。このうち左側は本来の空部からの遠赤外線が西壁に 鏡面反射したものと考えられ、さらに、空部の周りにも青く温度の 低い領域が観察される。同様な放射温度画像が 18:00 から翌日の 8:30まで得られた。これは、放射温度の低い面積が低放射率室の方 が広いことを意味している。この影響で低放射率室のグローブ温度 が標準室より低くなった(Fig. 4) と考える。Fig.5 の夕方から早朝に
かけて低放射率室の放射温度が他と比較して低くなったメカニズム に関しては、現在解析中である。空の内側にはアルミ箔を貼付して いないため、深夜から早朝において、通常の放射率を有する空部が 放射冷房面となり、グローブ温度を冷却する作用があることが確認 された。このとき、空気温度も低放射率室の方が低くなったが、こ の要因については引き続き分析していく。以上より、低放射化は放 射冷房にも効果があることが示唆される。同様に、13:00(Fig. 9 e、 f)の放射温度画像から、低放射率室で放射温度が高いこと示寸赤い 領域が広い。そのため、低放射率室の放射温度が急速に上昇し、そ れに伴い、低放射率室のグローブ温度が標準室より速くそして高く なったと考察される。空気温度に関しては、外気温との差が小さい (6月 6 日から 6 月 8 日の名古屋の日最高外気温の平均は $\left.31.1^{\circ} \mathrm{C}\right)$ た めに、両室に大きな差が現れなかったと考える。また、9:00(Fig. 9c、 d)においてはどちらの部屋も放射温度画像が黄緑色で一様で、表面 温度に大きな差がないことを示している。すなわち、熱放射環境に 影響を及ぼす放射冷房面や放射暖房面がないことに対応する。その ため、朝から昼にかけて 2 つの部屋の放射温度が同じになったもの と考える。

\section{5. まとめ}

本研究では、環境調和実験棟内に低放射率室と標準室を設置し、 放射暖房と組み合わせた際の室内温熱環境を比較することで、低放 射率表面材を建築室内空間に用いた際に形成される温熱環境や、放 射暖房と組み合わせたときの効果を定性的に明らかにした。標準室 と比較して低放射率室は、放射暖房によって空気温度およびグロー ブ温度が急速に上昇し、到達温度が $1^{\circ} \mathrm{C}$ 程度高い值を示した。これ は、ホットカーペットから放出される遠赤外線が壁や天井に吸収さ れないで反射によって室内に拡散し、電源投入直後に壁・天井の放 射温度が上がることにより、床面を除く全面が疑似的な放射暖房面 であるような空間となったためと推測される。また、気温の下がっ た夜における放射温度画像と空気温度およびグローブ温度から、低 放射率化により、通常の内装材と比較してより効率的な放射冷房が できると期待されることが判明した。さらに、壁面の低放射率化に よって放射暖房の立ち上がりの遅さを解消する可能性があることを 実証した。低放射化により熱放射に対する応答性が高まることから、 日射の影響の増幅が懸念される。そのため、低放射率内装材を用い る際には、適切に日射を制御する必要があると考えられる。本研究 では低放射率内装材としてアルミ䇴を使用したが、アルミ箔は鏡面 反射するため内装材としては不適当である。そのため、可視光域で の鏡面反射を低く抑えた低放射材料の開発も併せて行っている 12 。 今後は、対流式冷暖房機を使用した際の内装の低放射化による室内 温熱環境や冷暖房負荷に与える影響について検証する予定である。

\section{参考文献}

1) Izawa K., Mitobe M., Fukai Y., Asada H., Iwamatu T., Fukuda H., Ohkuma T., and Shukuya M.: Experimental Study on Thermal Comfort Provided by High-temperature Radiant Cooling and Low-temperature Radiant Heating Systems: Part 3. Environmental Quantities and Thermal Comfort Votes in the Winter Experiment, Summaries of Technical Papers of Annual Meeting, Architectural Institute of Japan, D-2, pp.585-586, 2007.7 (in Japanese)

井澤健輔, 三戸部元洋, 深井友樹, 浅田秀男, 岩松俊哉, 福田秀朗, 大熊武,宿谷 
昌則: 高温放射冷房と低温放射暖房の快適性に関する実験研究 その 3. 冬 季実験における環境物理量と快適申告, 日本建築学会大会学術講演梗概 集,D-2 分冊,pp.585-586,2007.7

2) Wada Takeshi et al.: A Study on the differences of thermal votes in case of radiative and convective cooling during short periods, Summaries of Technical Papers of Annual Meeting, Architectural Institute of Japan, Environmental Engineering, pp.343-344, 1994.7 (in Japanese) 和田剛志, 寺井 俊夫, 原田和典:短時間在室時における輻射冷房および対流 冷房が主観的温熱感に与える影響の差異に関する研究 一椅座安静・着衣の 場合一, 日本建築学会大会学術講演梗概集, 環境工学,pp.343-344,1994.7

3) Hong Seokchan et al.: A Study on evaluation of the thermal radiation envirnment in case of radiant cooling, Summaries of Technical Papers of Annual Meeting, Architectural Institute of Japan Kinki Branchi, pp.5356, 1993.6 (in Japanese)

洪錫賛, 寺井俊夫:輻射冷房時の輻射環境の評価に関する研究, 日本建築学会 大会近畿支部研究報告集,pp.53-56,1993.6

4) Ministry of Land, Infrastructure, Transport and Tourism: Data of Housing Economy (2018), Statistical data, Estimate by business operator questionnaire (2012),

http://www.mlit.go.jp/common/001133976.pdf, reference at 2021.1.29 (in Japanese)

国土交通省:平成 30 年度 住宅経済関連データ,統計データ, 事業者アンケー トにより推計(平成 24 年), 参照 2021.1.29

5) Yano Research Institute, Press Release, 2019.7.8, accessed 2020.10.1 (in Japanese)

矢野経済研究所プレスリリース, 2019.7.8,参照 2020.10 .1

: https://www.yano.co.jpp.ress-release/show/press_id/2177

6) Shoko, K., Ryo, N., Makoto, S. and Masayuki, M.: Satisfaction and Implementation Details of Remodeling for Existing Detached Houses Considering the Factors of Insulation Remodeling -, Journal of Architecture and Planning (Transactions of AIJ), vol.85, No.773, pp.1407-1415, 2020.7 (in Japanese)

神代翔子, 中村遼, 佐藤誠, 前真之: 既存戸建住宅のリフォームの満足度及び 実施内容に関する研究 一断熱性能向上リフォームの実施要因の考察一, 日本建築学会計画系論文集,第 85 巻,第 773 号,pp.1407-1415,2020.7

7) Architectural Institute pf Japan Environmental Standards: Academic Standards for Measurement of Indoor Environments AIJES-H002-2008, Architectural Institute of Japan, Maruzen, pp.25-27, 2008.3 (in Japanese)

日本建築学会環境基準AIJES-H002-2008: 室内温熱環境基準. 同解説, 日本 建築学会, 丸善, pp.25-27,2008. 3

8) Architectural Institute pf Japan Environmental Standards: Academic Standards for Measurement of Indoor Environments AIJES-H002-2008, Architectural Institute of Japan, Maruzen, pp.17-20, 2008.3 (in Japanese)

日本建築学会環境基準 AIJES-H002-2008: 室内温熱環境基準. 同解説, 日本 建築学会, 丸善,pp.17-20,2008.3

9) Asada H., Ishinami M., and Yamada Y.: Study of the Effects of Low Emissivity Surface Materials on Indoor Thermal Environments when Performing Radiant Heating: Part 1. , Journal of Japan Solar Energy Society (2019), pp.111-114, 2019.10 (in Japanese)

浅田秀男, 石並真吏, 山田保誠: 低放射率表面材が放射暖房時の室内温熱環境 に及ぼす効果に関する研究その 1 . 単室模型を用いた実験概要と温熱環境 形成メカニズム, 日本太陽エネルギー学会講演論文集 (2019),pp.111$114,2019.10$

10) Ishinami M., Asada H., and Yamada Y.: Study of the Effects of Low Emissivity Surface Materials on Indoor Thermal Environments when Performing Radiant Heating: Part 2. The Effect of the Difference in Position Between the Low Emissivity Surface and the Radiant Heating Surface, Journal of Japan Solar Energy Society (2019), pp.115-116, 2019.10 (in Japanese)

石並真吏,浅田秀男,山田保誠: 低放射率表面材が放射暖房時の室内温熱環境 に及ぼす効果に関する研究その 2. 低放射率面の部位と放射暖房面位置の 違いが及ぼす影響, 日本太陽エネルギー学会講演論文集 (2019),pp.115$116,2019.10$

11) Asada H., Ishinami M., and Yamada Y.: Study on Effects of a Low
Emissivity Interior Surface Material for Thermal Environment of a Room with Floor Heating System and Energy Use for Heating: Part 1. Outline of the Experiment Using Model Chambers and Effect on Interior Thermal Environment, Summaries of Technical Papers of Annual Meeting, Architectural Institute of Japan, Environmental Engineering, pp.1271-1272, 2020.7 (in Japanese)

浅田秀男, 石並真吏, 山田保誠:低放射率表面材が放射暖房室の温熱環境・暖 房用エネルギー使用量に及ぼす効果に関する研究その 1 . 単室模型を用い た実験概要と温熱環境に及ぼす効果, 日本建築学会大会学術講演梗概集, 環 境工学,pp.1271-1272,2020.7

12) Ishinami M., Asada H., and Yamada Y.: Study on Effects of a Low Emissivity Interior Surface Material for Thermal Environment of a Room with Floor Heating System and Energy Use for Heating: Part 2. Effect on Thermal Environment and Electricity Consumption for Radiant Heating by the Differences of Position and area of Lowemissivity Surfaces, Summaries of Technical Papers of Annual Meeting, Architectural Institute of Japan, Environmental Engineering, pp.12731274, 2020.7 (in Japanese)

石並真吏, 浅田秀男, 山田保誠:低放射率表面材が放射暖房室の温熱環境・暖 房用エネルギー使用量に及ぼす効果に関する研究その 2. 低放射率面と放 射暖房面の部位の違いが温熱環境および暖房用エネルギー使用量に及ぼす 効果, 日本建築学会大会学術講演梗概集,環境工学,pp.1273-1274,2020.7

13) Yamada Y., Asada H., and Ishinami M.: Study on Effects of a Low Emissivity Interior Surface Material for Thermal Environment of a Room with Floor Heating System and Energy Use for Heating: Part 3. Effect on Interior Thermal Environment by Radiation Heating Using Real-size Experimental Rooms with Low-e Interior Surface and Normal Interior Surface, Summaries of Technical Papers of Annual Meeting, Architectural Institute of Japan, Environmental Engineering, pp.1275 1276, 2020.7(in Japanese) 山田保誠, 浅田秀男, 石並真吏:低放射率表面材が放射暖房室の温熱環境・暖 房用エネルギー使用量に及ぼす効果に関する研究その 3. 実大実験室を用 いた放射暖房による温熱環境の比較, 日本建築学会大会学術講演梗概集, 環境工学,pp.1275-1276,2020.7 


\title{
EFFECTS OF LOW EMISSIVITY INTERIOR SURFACES ON THERMAL ENVIRONMENT (PART 1): MEASUREMENTS ON INTERNAL THERMAL ENVIRONMENT WITH RADIANT HEATING USING REAL-SIZE EXPERIMENTAL ROOMS
}

\author{
Maori ISHINAMI ${ }^{* 1}$, Hideo ASADA ${ }^{* 2}$ and Yasusei YAMADA ${ }^{* 3}$ \\ ${ }^{11}$ Research Assist., AIST, M.A. / Grad. Student, Dept. of Creativity and Culture, \\ Graduate School of Creativity and Culture, Aichi Shukutoku Univ., M.A. \\ ${ }^{2}$ Prof., Fac. of Creation and Representation, Aichi Shukutoku Univ., Dr.Eng. \\ ${ }^{3}$ Group Leader, AIST, Dr.Eng.
}

\begin{abstract}
Since typical interior materials have high-emissivity surface of about 0.9 , far-infrared generated from radiant heater is absorbed once in interior walls and then reradiated infrared from the warmed walls reaches human body surfaces. In the case of low-emissivity (low-E) interior surface of about 0.1 , generated far-infrared is reflected at interior wall surface and reaches human body surfaces without warming processes of walls. Thus, it is expected that human body feels warmth quickly and/or heating load can reduce owing to the decrease in set temperature by forming the room covered with low-E materials. Therefore, we studied effects of the low-E interior surface material on interior thermal environment using radiant heating by comparing two real-size experimental rooms with the same thermal insulation: one is covered with a low-E material, aluminum foil (Low-E room), and the other is covered with a normal interior material (Std-E room).

When warm up the rooms using electrically heated carpet as radiant heating equipment, the globe and air temperatures of the Low-E room increased rapidly and showed about $0.8^{\circ} \mathrm{C}$ higher temperatures than those of Std-room in $30 \mathrm{~min}$. The radiant temperatures of the wall and ceiling of Low-E room increased immediately with the increase in the temperature of the carpet by turning on, while slow increase in those of Std-E room. Thus, the increase in globe and in air temperatures of the Low-E room may be because the whole Low-E surface, except for floor, of the room become pseudo radiant heating surface.

In this study we used aluminum foil as low-E materials. However, this material is not suitable for interior due to high specular reflection. Therefore, novel materials with low specular reflection in the visible range and low emissivity in the far -infrared range are also developing at present.
\end{abstract}

